Research Article

\title{
Contamination Features and Source Apportionment of Heavy Metals in the River Sediments around a Lead-Zinc Mine: A Case Study in Danzhai, Guizhou, China
}

\author{
Rongguo Sun, ${ }^{1}$ Yue Gao, ${ }^{1}$ Jing Xu, ${ }^{1}$ Yang Yang, ${ }^{2}$ and Yutao Zhang $\mathbb{C}^{3}$ \\ ${ }^{1}$ School of Chemistry and Material, Guizhou Normal University, Guiyang 550025, China \\ ${ }^{2}$ School of Life Sciences, Guizhou Normal University, Guiyang 550025, China \\ ${ }^{3}$ Engineering Technology Center for Control and Remediation of Soil Contamination, Anshun University, Anshun 561000, China
}

Correspondence should be addressed to Yutao Zhang; zyt0516@126.com

Received 23 March 2021; Accepted 18 May 2021; Published 26 May 2021

Academic Editor: Kaustubha Mohanty

Copyright ( 2021 Rongguo Sun et al. This is an open access article distributed under the Creative Commons Attribution License, which permits unrestricted use, distribution, and reproduction in any medium, provided the original work is properly cited.

The spatial patterns, ecological risks, and sources of heavy metals (HMs), including $\mathrm{Pb}, \mathrm{Zn}, \mathrm{Mn}, \mathrm{Cu}, \mathrm{Cd}, \mathrm{Hg}$, and $\mathrm{As}$ in river sediments, were identified around a lead-zinc mine of Danzhai, Guizhou, China. The concentrations of selected HMs and their coefficient variations indicated that the river sediments around this typical lead-zinc mine were obviously contaminated with HMs. Anthropogenic activities had further enhanced the accumulation of HMs. The higher contents of the most common selected HMs were mainly distributed in the area close to the lead-zinc mine. Based on the combined evaluations of the single factor pollution index, geo-accumulation index, and potential ecological risk index, it indicated that the ecological risks of $\mathrm{Hg}, \mathrm{Cd}, \mathrm{Zn}$, and $\mathrm{Pb}$ were high or extremely high, and of $\mathrm{Mn}, \mathrm{Cu}$, and $\mathrm{As}$ were slight or none in the sediments around this lead-zinc mine. It was found that lead-zinc mining and smelting activities, coal mining activities, and agricultural activities (livestock and poultry breeding) are the primary sources of selected HMs, based on the results of correlation analysis together with principal component analysis (PCA) and positive matrix factorization (PMF) model. The pollution of HMs in the river sediments around a lead-zinc mine was predominantly caused by lead-zinc mining and smelting activities. Therefore, for environmental persistence, lead-zinc mining and smelting activities should be given careful consideration and under close surveillance.

\section{Introduction}

Heavy metals (HMs) are regarded as serious contaminations in water systems due to their environmental persistence, toxicity, nonbiodegradable properties, and accumulative behaviors $[1,2]$. HMs pollution in water systems has caused wide concerns throughout the world, especially in developing countries where the economic activities are extensive [3]. Sediments are an important sink in aquatic ecosystems for HMs emitted from anthropogenic sources and will directly affect the overlying water and aquatic organisms $[4,5]$. The concentrations of HMs in sediments can reflect the quality of the water column to some extent [6]. HMs can release into the overlying water and result in some secondary contamination problems when the environmental conditions change [7]. The spatial pattern of HMs can vividly present the concentrations of HMs (high or low) in the selected study area. The risk assessment of HMs would provide theoretical support for risk management. Numerous evaluation methods, such as geo-accumulation index $\left(I_{\text {geo }}\right)$, potential ecological risk index (PERI), single factor pollution index $\left(P_{i}\right)$, fuzzy coefficient method, gray clustering method, etc., have been applied to evaluate the contamination of HMs in the environment [8-12]. The selection of evaluation methods should consider their emphasis and the research purpose [13]. In general, multiple evaluation methods were conducted to obtain comprehensive results $[5,14]$.

The contents of HMs in the sediments around the areas with extensive economic activities mainly depend on anthropogenic activities such as rapid industrialization, mining, and smelting mineral resources, nonjudicial use of agrochemical, urbanization, agricultural production, etc. 
$[15,16]$. These activities had resulted in that HMs were accumulated in soil and water systems and thus declined the environment quality over the past few decades in China $[13,17-21]$. In addition to anthropogenic sources, natural processes such as atmospheric sedimentation, rainfall, and rock weathering are important sources for HMs in the environment [22]. Therefore, it is necessary to identify the different sources of HMs in sediments [23], which could provide certain guidelines for the government to protect the aquatic ecosystems that are polluted with HMs [24].

There are multiple methods used to investigate the potential sources of HMs in soil and water environment, which include correlation analysis, principal component analysis (PCA), positive matrix factorization, geographic information systems, enrichment factor, etc. [23, 25-29]. Although these methods can identify the common characteristics of selected HMs quickly via classification or dimension reduction, they cannot calculate the contribution rates of each heavy metal [30-33]. In addition to these methods, positive matrix factorization (PMF) provides an ideal receptor that has been used to characterize the sources of contaminations in soil, sediments, and particulate matter [34-36].

Danzhai, located in the southeast of Guizhou province, China, abounds with minerals such as lead, zinc, coal, Mercury, gold, etc. A long-term of more than 600 years of $\mathrm{Hg}$ mining activities have experienced in Danzhai, causing serious $\mathrm{Hg}$ pollution in soil $[37,38]$. Moreover, lead, zinc, coal, and gold mining and smelting activities had developed rapidly in recent years. Large amounts of gangues and mine tailings are controlled stockpiled stacked optionally near mining sites. The acid mine drainage (AMD) generated from these solid wastes contains a high level of HMs and enters into the soil and aquatic environment under the impact of rainfall. Once the AMD enters the aquatic environment, the HMs will be accumulated in sediments, resulting in serious contamination of HMs in large mining areas [13, 39]. Therefore, we hypothesized that the sediments around mining and smelting sites are polluted with HMs seriously, with a certain spatial distribution pattern. Given the above consideration, the main objectives of this research were to (1) characterize the spatial patterns of $\mathrm{HMs}(\mathrm{Pb}, \mathrm{Zn}, \mathrm{Mn}, \mathrm{Cu}$, $\mathrm{Cd}, \mathrm{Hg}$, and As) in the sediments around a typical lead-zinc mine, (2) evaluate the ecological risks of selected HMs to the aquatic ecosystem, and (3) accurately apportion the sources of HMs and identify their contributions in the study area for guiding restoration strategies using PMF model.

\section{Materials and Methods}

2.1. Site Description and Sample Collection. The lead-zinc mine is located southeast of Guizhou, China (Figure 1). Mining and smelting activities started in 2005. This region has complicated topography and a variety of landforms. The general altitudes range from 700 to 1100 above sea level. This area has a subtropical monsoon humid climate, with annual mean temperatures of $12.6-17.2^{\circ} \mathrm{C}$ with annual precipitations of $1259.7-1508.4 \mathrm{~mm}$.
Surface sediments with a depth of $5 \mathrm{~cm}$ from 8 sites were collected in April 2019. The samples were transferred to the laboratory within 6 hours with preserving them in self-styled bags under $4^{\circ} \mathrm{C}$. Site $\mathrm{S} 1$ is a livestock rearing area and is located in the upstream region of the lead-zinc mine. Sites S2 and $\mathrm{S} 4$ are just under the accumulation area of slag. Site S3 is the paddy field just under the accumulation area of slag. Sites S5-S8 are located in the river around this lead-zinc mine.

2.2. Chemical Analyses and Data Analysis. The preparation, digestion, and determination of sediment samples have been described in our previous work [5]. Simply, the sediment samples were dried freeze, dislodged the stones, debris, and organisms, and ground to 200-mesh. The ground samples were dispelled with $\mathrm{HNO}_{3}, \mathrm{HF}$, and $\mathrm{HClO}_{4}$ under $25^{\circ} \mathrm{C}$ for 12 hours. Then these acids were volatilized at $160^{\circ} \mathrm{C}$ until solidified material became light yellow or white. The solidified material was dissolved with $\mathrm{HNO}_{3}$ and diluted with ultrapure water for determination [5]. Flame atomic absorption spectrometry (Perkin Elmer AAnalyst 800, USA) was employed for determining $\mathrm{Pb}, \mathrm{Cu}, \mathrm{Zn}$, and $\mathrm{Mn}$, graphite furnace atomic absorption spectrometry was used for measuring $\mathrm{Cd}$, and cold atomic fluorescence spectrometry (Model III, Brooks Rand, USA) was employed for determining As and $\mathrm{Hg}$, in prepared solution [5].

The recovery rates of Chinese national standard material (GSS-8) were determined to be $94 \pm 2 \%, 90 \pm 4 \%, 97 \pm 3 \%$, $103 \pm 5 \%, 98 \pm 4 \%, 112 \pm 7 \%$, and $106 \pm 2 \%$ for $\mathrm{Pb}, \mathrm{Zn}, \mathrm{Mn}$, $\mathrm{Cu}, \mathrm{Cd}, \mathrm{Hg}$, and As, respectively. The relative standard deviation (\%RSD) of all samples was less than 6\%. The procedure of method blanks (stochastic $15 \%$ of samples) was conducted as detecting real samples, and contaminations were not found during analysis.

The single factor pollution index $\left(P_{i}\right)[12,40]$, geo-accumulation index $\left(I_{\text {geo }}\right)$ [9], and potential ecological risk index (PERI) $[8,41,42]$ were employed to evaluate the pollution status of HMs in the sediments around this leadzinc mine. A detailed description of these three evaluation methods is provided in supplementary materials. The source of HMs in sediments around a lead-zinc Mine was apportioned by positive matrix factorization (PMF 5.0) [43], which was presented in supplementary materials.

\section{Results and Discussions}

3.1. Overview and Spatial Patterns of HMs. Table 1 displays the descriptive data of HMs in the sediments around this lead-zinc mine. The average concentrations of $\mathrm{Pb}, \mathrm{Zn}, \mathrm{Cd}$, $\mathrm{Mn}$, and $\mathrm{Hg}$ were 2.91, 4.32, 1.05, 3.79, and 18.6 times greater than their own corresponding background values, which indicated that the sediments were obviously polluted with these metals. Based on the values of coefficient variations for HMs, the degree of variation can be classified as high variation $(>36 \%)$, moderate variation (16\%-36\%), and low variation $(<16 \%)$ [44]. Although both the concentrations of $\mathrm{Cu}$ and As were lower than their own corresponding background levels, the coefficient variations of these two 


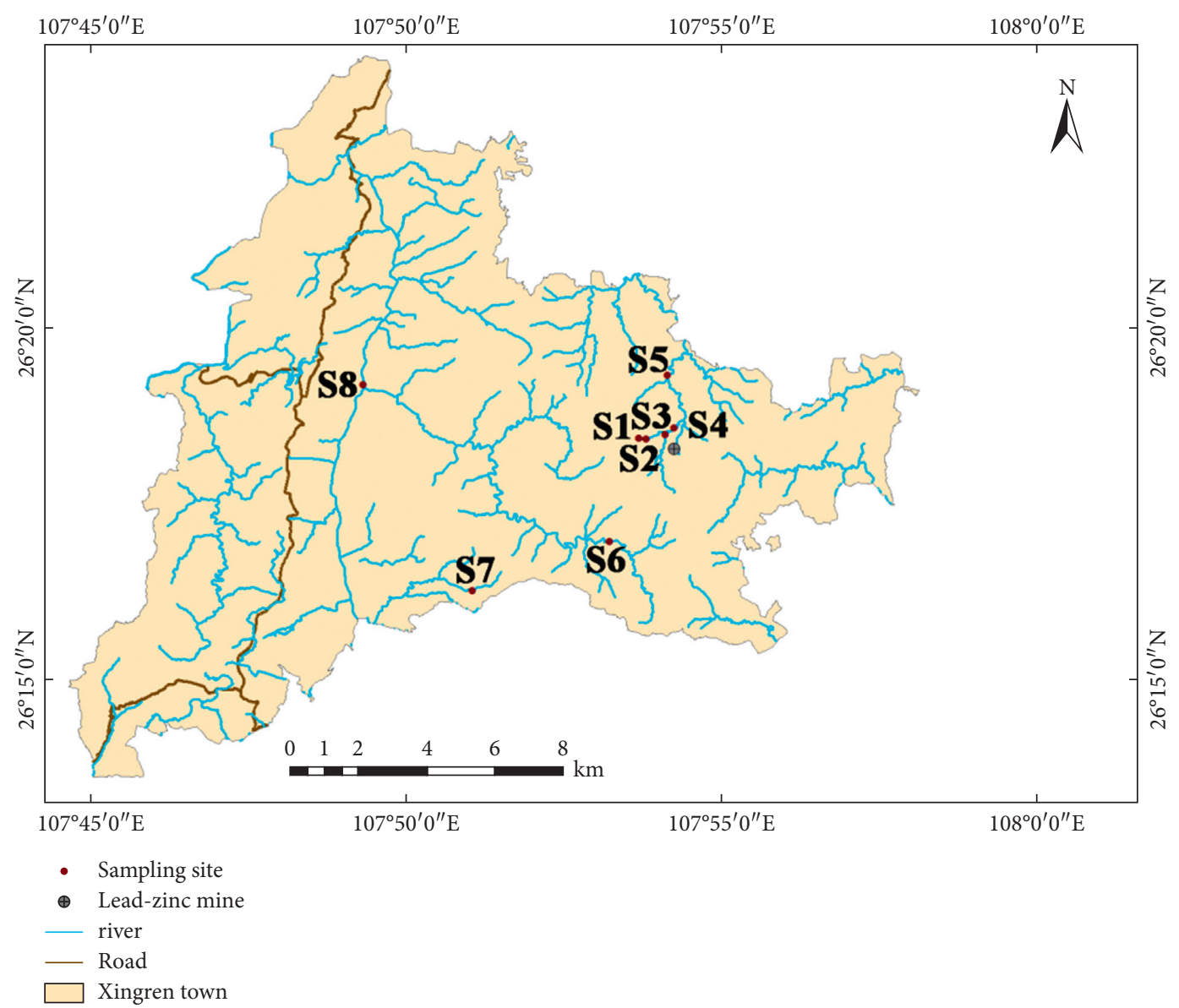

Figure 1: Study area and the location of 8 sampling sites.

TABLe 1: The descriptive of HMs in the sediments around this lead-zinc mine $\left(\mathrm{mg} \mathrm{kg}^{-1}\right)$.

\begin{tabular}{lccccc}
\hline $\mathrm{HMs}$ & Maximum & Minimum & Mean \pm std. & Coefficient of variation (\%) & Background values \\
\hline $\mathrm{Pb}$ & 276.55 & 30.79 & $102.45 \pm 86.87$ & 85 & 77 \\
$\mathrm{Zn}$ & 842.05 & 124.97 & $429.54 \pm 330.59$ & 59 & 99.5 \\
$\mathrm{Mn}$ & 1746.36 & 191.90 & $830.91 \pm 488.27$ & 68 & 794 \\
$\mathrm{Cu}$ & 83.97 & 18.03 & $31.77 \pm 21.59$ & 28 & 32 \\
$\mathrm{Cd}$ & 3.15 & 0.89 & $2.51 \pm 0.69$ & 95 & 0.66 \\
$\mathrm{Hg}$ & 6.34 & 0.62 & $2.04 \pm 1.94$ & 51 & 0.11 \\
$\mathrm{As}$ & 13.22 & 3.65 & $7.26 \pm 3.69$ & 20 \\
\hline
\end{tabular}

metals were high. The values of coefficient variations for $\mathrm{Cd}$ showed a moderate variation. The other metals showed a high variation and indicated that anthropogenic effects could result in the accumulating of HMs in sediments [45].

The concentrations of all HMs in sediments showed significant variations among the sampling sites (Figure 2). The comparatively high levels of $\mathrm{Pb}, \mathrm{Hg}, \mathrm{Cu}$, and $\mathrm{Zn}$ in the sediments were generally exhibited in Sites S3, S4, and S5. The contents of Mn, S3, S4, and S5 had low values, indicating an opposite tendency of the distribution characteristics of $\mathrm{Pb}, \mathrm{Zn}, \mathrm{Cu}$, and $\mathrm{Hg}$. The peak concentrations of $\mathrm{Cd}$ can be found in sites S1 and S3-S7. The higher concentrations of As were mainly distributed in sites S2, S3, and S5. The contents of $\mathrm{Zn}, \mathrm{Cd}$, and $\mathrm{Hg}$ in sediments in all sampling sites were higher than their own corresponding background levels. The contents of $\mathrm{Pb}$ in sties $\mathrm{S} 7$ and $\mathrm{S} 8, \mathrm{Mn}$ in sites $\mathrm{S} 3-\mathrm{S} 5, \mathrm{~S} 5, \mathrm{~S} 6$, and S8, Cu in sites S1, S2, S4, and S6-S8, As in all sites, did not exceed their own corresponding background values. It is indicated that the higher levels of some $\mathrm{HMs}(\mathrm{Pb}, \mathrm{Hg}, \mathrm{Cu}$, and $\mathrm{Zn}$ ) were mainly distributed in the area near this leadzinc mine. These results also demonstrated that the accumulation degrees of $\mathrm{Cd}$ and Mn were complex and that there was nonpollution with As in our study area.

3.2. Ecological Risk. As shown in Figure 3(a), the $P_{i}$ of $\mathrm{Hg}$ in sediments around this lead-zinc mine peaked in site S3 (57.62), followed by S5 (23.88), S4 (21.57), S8 (20.81), S1 (7.23), S2 (6.05), S7 (5.64), and S6 (5.63). All the values of $P_{i}$ for $\mathrm{Hg}$ in every site were higher than 3 , which indicated that 


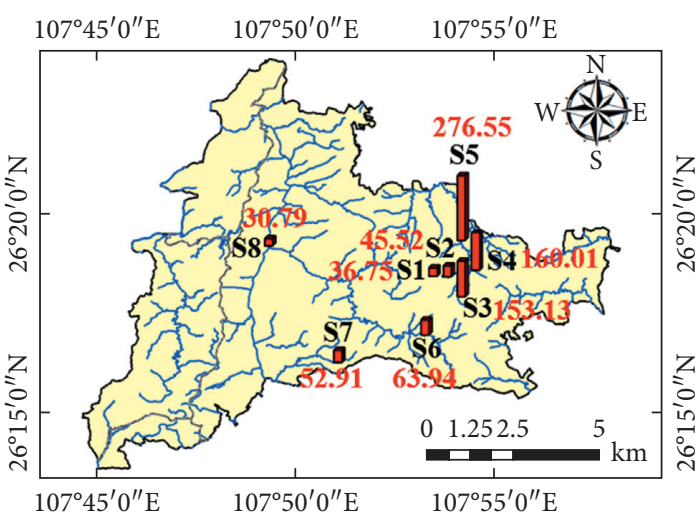

(a)

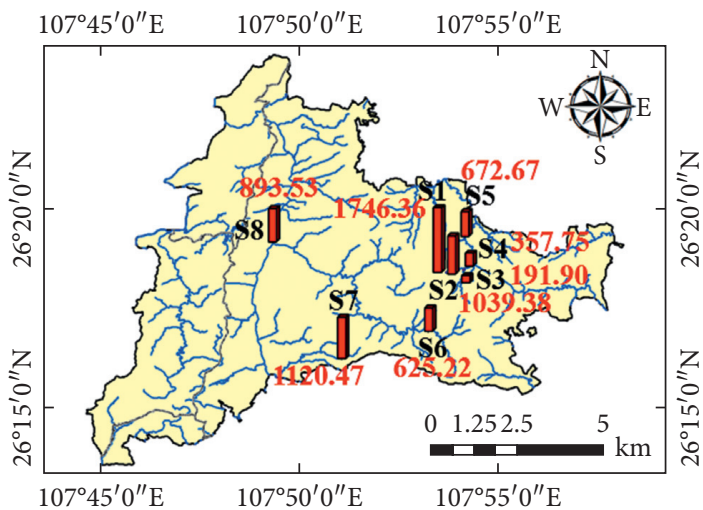

(c)

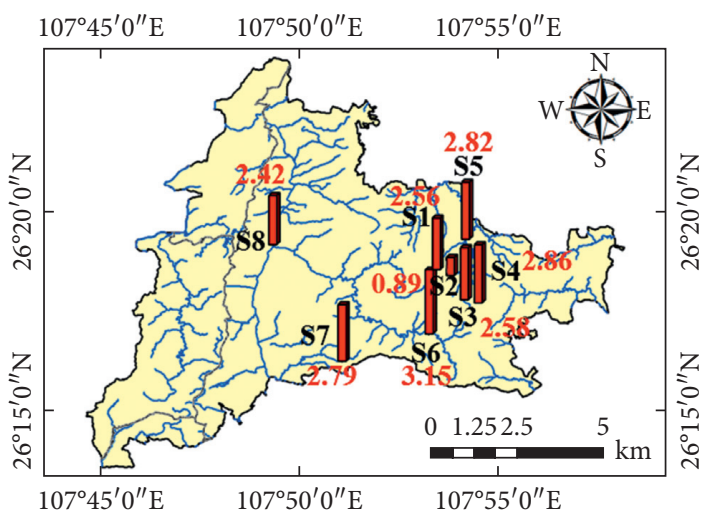

(e)

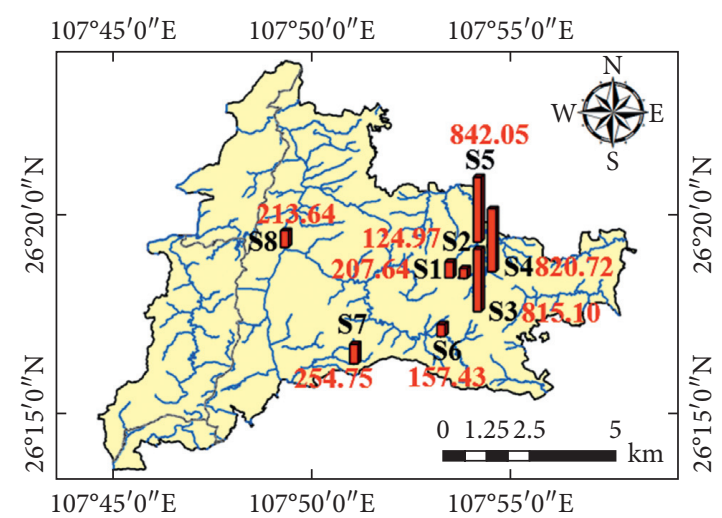

(b)

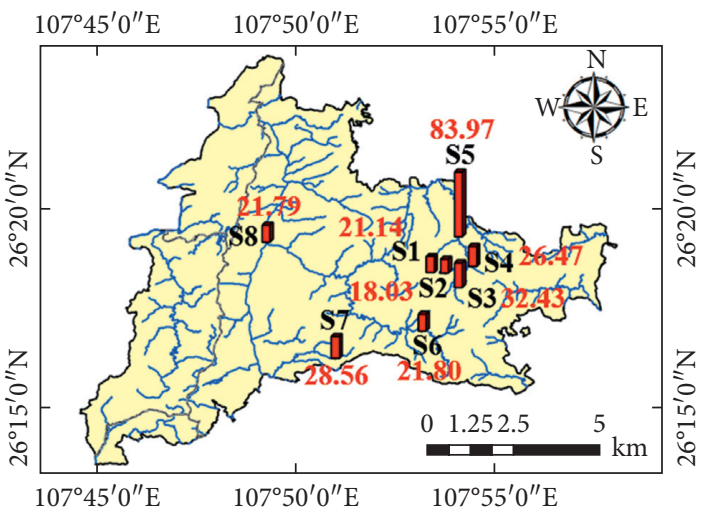

(d)

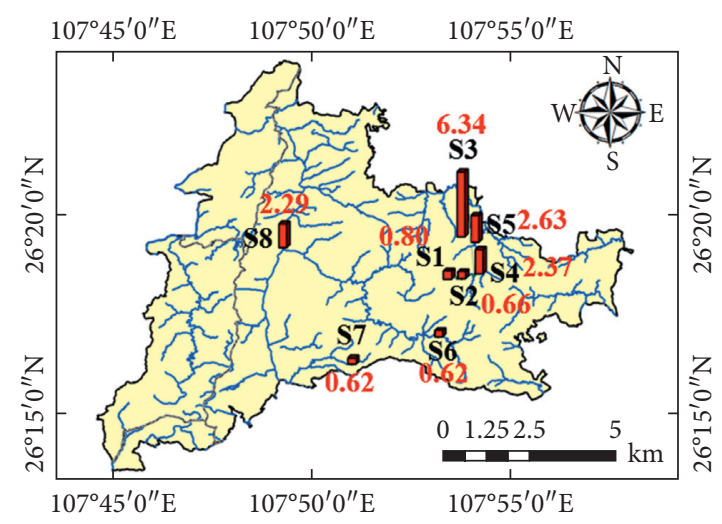

(f)

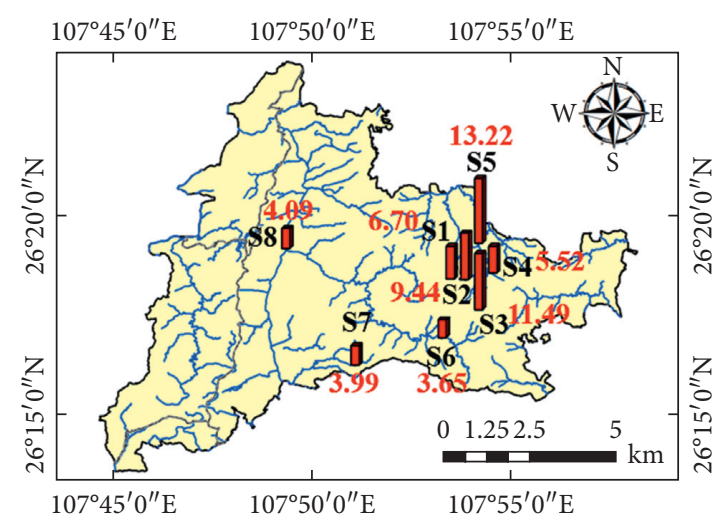

(g)

FIGURE 2: Spatial distribution maps of average contents of HMs in the sediments in the study area. (a) $\mathrm{Pb}\left(\mathrm{mg} \mathrm{kg}^{-1}\right)$, (b) $\mathrm{Zn}\left(\mathrm{mg} \mathrm{kg}^{-1}\right)$, (c) $\mathrm{Mn}$ $\left(\mathrm{mg} \mathrm{kg}^{-1}\right)$, (d) $\mathrm{Cu}\left(\mathrm{mg} \mathrm{kg}^{-1}\right)$, (e) $\mathrm{Cd}\left(\mathrm{mg} \mathrm{kg}^{-1}\right)$, (f) $\mathrm{Hg}\left(\mathrm{mg} \mathrm{kg}^{-1}\right)$, (g) As $\left(\mathrm{mg} \mathrm{kg}^{-1}\right)$. 


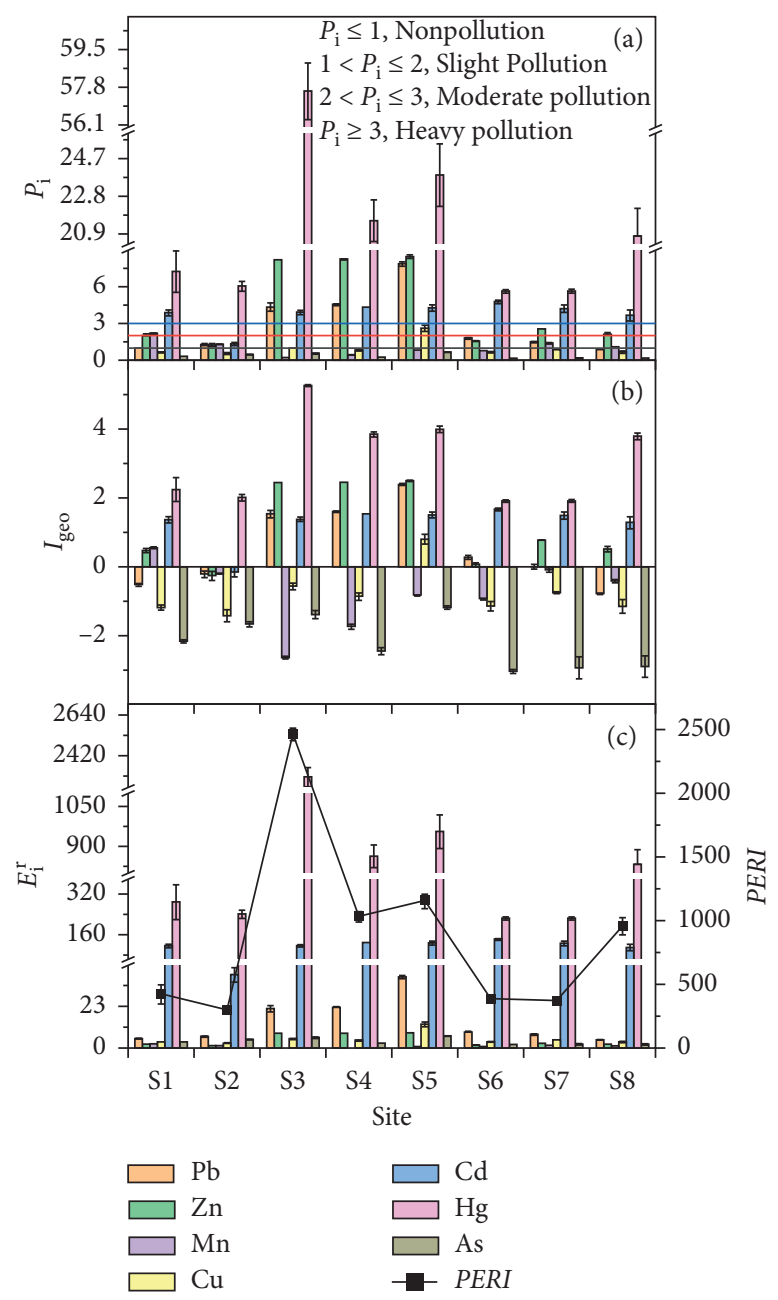

FIgURE 3: Evaluation results with $P_{i}(\mathrm{a}), I_{\text {geo }}(\mathrm{b})$, and PERI (c) for the pollution status of HMs in sediments around this lead-zinc mine.

the sediments around this lead-zinc mine were heavily polluted with $\mathrm{Hg}$. The $P_{i}$ of $\mathrm{Zn}$ in the sediments around the lead-zinc mine were higher than 3 in sites S3, S4, and S5, showing heavy pollution with $\mathrm{Zn}$ in these sites. The $P_{i}$ of $\mathrm{Zn}$ in the sediments of sites S1, S7, and S8 were between 2 and 3, which indicated that these sediments were moderately polluted with Zn. Sites S2 and S6 were slightly polluted with $\mathrm{Zn}$ because the $P_{i}$ of $\mathrm{Zn}$ in the two sites were between 1 and 2 . The $P_{i}$ of Cd in the sediments of all sites except site S2 (1.35) were calculated to be more than 3 , indicating that the sediments around this lead-zinc mine were heavily polluted with $\mathrm{Cd}$. The $P_{i}$ of $\mathrm{Pb}$ in sediments of sites S3, S4, and S5 were higher than 3, sites S2, S6, and S7 were between 1 and 2, and sites S1 and S8 were lower than 1. It was found that sites S3, S4, and S5 showed heavy pollution, sites S2, S6, and S7 showed slight pollution, and sites S1 and S8 showed nonpollution with $\mathrm{Pb}$. The sediments in most sites around leadzinc mine were nonpollution or slight pollution caused by $\mathrm{Cu}$ and $\mathrm{Mn}$ because their $P_{i}$ were lower than 1 or 2 . The $P_{i}$ of As in all sites were lower than 1 , indicating that there were nonpollution caused by As. The mean $P_{i}$ of $\mathrm{Hg}, \mathrm{Zn}, \mathrm{Cd}, \mathrm{Pb}$, $\mathrm{Mn}, \mathrm{Cu}$, and $\mathrm{As}$ in all sites were calculated to be $18.55,4.32$, $3.80,2.91,1.05,0.99$, and 0.36 , respectively. This indicates that the sediments around the lead-zinc mine are heavily polluted with $\mathrm{Hg}$, $\mathrm{Zn}$, and $\mathrm{Cd}$, moderately polluted with $\mathrm{Pb}$, slightly polluted with $\mathrm{Mn}$, and nonpollution with $\mathrm{Cu}$ and $\mathrm{As}$ as a whole.

By comparing the current concentrations of HMs with their corresponding background values, the $I_{\text {geo }}$ can figure out the contamination status of HMs in environment [2]. Therefore, the $I_{\text {geo }}$ were calculated for understanding the pollution level of HMs with respect to natural environment in the sediments around this lead-zinc mine. Although there are no background concentrations of HMs recorded in the sediments in Danzhai, the $I_{\text {geo }}$ can be calculated as a function of background contents of soil elements in Guizhou Province, China. The overall value of $I_{\text {geo }}$ ranged from -0.78 to 2.39 for $\mathrm{Pb},-0.26$ to 2.50 for $\mathrm{Zn},-2.63$ to 0.55 for $\mathrm{Mn},-1.42$ to 0.80 for $\mathrm{Cu},-0.15$ to 1.67 for $\mathrm{Cd}, 1.91$ to 5.26 for $\mathrm{Hg}$, and -3.04 to -1.18 for As. The rank order of mean values of $I_{\text {geo }}$ for these $\mathrm{HMs}$ were $\mathrm{Hg}($ mean 3.12) $>\mathrm{Cd}($ mean 1.26) $>\mathrm{Zn}$ $($ mean 1.12$)>\mathrm{Pb}($ mean 0.54$)>\mathrm{Mn}($ mean -0.78$)=\mathrm{Cu}$ (mean -0.78) $>$ As (mean -2.21) (Figure 3(b)). This suggested that the sediments around this lead-zinc mine were heavily polluted with $\mathrm{Hg}$, moderately polluted with $\mathrm{Cd}$ and $\mathrm{Zn}$, slightly polluted with $\mathrm{Pb}$, and nonpollution with $\mathrm{Mn}, \mathrm{Cu}$, 
and As. The status of $\mathrm{Hg}$ contamination in the sediment of each site was ranked in the order of S3 (extreme pollution) $>$ S4, S5, and S8 (heavy pollution) > S6 and S7 (moderate pollution). The surface sediments were moderate pollution of Cd throughout the study area, expect for site S2 (nonpollution). The degrees of $\mathrm{Zn}$ contamination were determined to be heavy pollution in sites S3, S4, and S5, slight pollution in sites S1, S6, S7, and S8, and nonpollution in site $\mathrm{S} 2$. The degree of $\mathrm{Pb}$ contamination was determined to be moderate to heavy pollution in sites S5, moderate pollution in S3 and S4, slight pollution in sites S6 and S7, and nonpollution in sites S1, S2, and S8. All sampling sites were determined to be nonpollution with $\mathrm{Mn}, \mathrm{Cu}$, and As except for S1 (slight pollution with Mn) and S5 (slight pollution with $\mathrm{Cu}$ ). It was found that all sites were contaminated with $\mathrm{Hg}$ and $\mathrm{Cd}$. In addition, the sediments near the lead-zinc mine were also contaminated with $\mathrm{Pb}$ and $\mathrm{Zn}$.

According to the mean values of $E_{i}^{r}$

of each element, the highest single risk index was $\mathrm{Hg}$ (742.15), followed by Cd (114.06), $\mathrm{Pb}$ (14.55), Cu (4.96), $\mathrm{Zn}$ (4.32), As (3.63), and Mn (1.05) (Figure 3(c)). This demonstrated that the ecological risks induced by $\mathrm{Pb}, \mathrm{As}, \mathrm{Zn}$, $\mathrm{Mn}$, and $\mathrm{Cu}$ were low for the sediments around lead-zinc mine. The values of $E_{i}^{r}$

for Cd in all sites were between 80 and 160 except sites S2 $(40.61 \pm 4.0)$, indicating Cd caused considerable potential ecological risk for the sediments around lead-zinc mine. The values of $E_{i}^{r}$

for $\mathrm{Hg}$ were calculated to be between 160 and 320 in sediments of sites S1, S2, S6, and S7, and more than 320 in the other sites. This demonstrated that $\mathrm{Hg}$ caused a high risk for half of the study area and extremely high risk for the other half. Besides, both $\mathrm{Hg}$ and $\mathrm{Cd}$ are significant polluted elements in the sediments around this lead-zinc mine.

The PERI is the sum of potential risk for selected HMs, which can figure out their combined toxicology, ecological, and environmental effects based on HMs contents [8]. PERI values in site S3 $(2463 \pm 48)$, S4 $(1031 \pm 41)$, S5 $(1152 \pm 88)$, and S8 $(955 \pm 68)$ were higher than 600 , demonstrating that HMs in these areas had extremely high risk. For the rest of the sampling sites, PERI values were equal to or more than 300 , which suggested that these sites posed considerable risk with HMs. Hg and $\mathrm{Cd}$ had the highest contributions to PERI (77.02\% and $19.08 \%$, respectively), which induced high PERI values in the sediments of this study area, especially in the sites near mining sites, e.g., sites S3 and 4. The contribution rate of the other individual heavy metal was calculated to be lower than 1 , and their sum was $2.23 \%$. It was found that the sediments in the study area were polluted at different degrees with various $H M s$ based on the evaluation with $P_{i}, I_{\text {geo }}$, and PERI. $\mathrm{Hg}, \mathrm{Cd}, \mathrm{Zn}$, and $\mathrm{Pb}$ should be given careful consideration among these HMs. There were slightly polluted or nonpolluted with $\mathrm{As}, \mathrm{Mn}$, and $\mathrm{Cu}$ in the sediments around this lead-zinc mine.

3.3. Correlation Analysis. If the HMs came from similar single or multiple sources, their contents in sediments would present positive relationships and vice versa. Relationships among selected HMs were thus analyzed by using Spearman's correlation. It showed that there were positive relations among almost all HMs except Mn (Table S3). What's noted is that there were statistically significant correlations between $\mathrm{As}, \mathrm{Zn}, \mathrm{Cu}$, and $\mathrm{Pb}$. This showed that these HMs might come from the same sources related to anthropogenic activities, including mining and smelting, industrial production, and coal-fired power, etc. [31, 46, 47]. In our study area, the lead-zinc mine is the obvious pollution source for HMs. Therefore, we concluded that $\mathrm{As}, \mathrm{Zn}, \mathrm{Pb}$, and $\mathrm{Cu}$ in the sediments were mainly from lead-zinc mining and smelting factory. Negative correlations were found between $\mathrm{Mn}$ and $\mathrm{Pb}, \mathrm{Zn}$, and $\mathrm{Cd}$, indicating that lead-zinc mining and smelting factory is not the source of Mn for the sediments in the study area around the lead-zinc mine. The spatial distribution characteristics of HMs in sediments (Figure 2) confirmed this point. The contents of Mn were higher in the sites where the contents of $\mathrm{As}, \mathrm{Zn}, \mathrm{Pb}$, and $\mathrm{Cu}$ were lower. Positive relationships were found between $\mathrm{Hg}$ and the other metals, especially $\mathrm{Zn}$, with a significant coefficient of $0.717^{*}$

. This indicated that lead-zinc mining and smelting factory was not the only source of $\mathrm{Hg}$; some other sources such as large-scale $\mathrm{Hg}$ mining activities and atmospheric deposition of $\mathrm{Hg}$ might also affect the concentrations of $\mathrm{Hg}$ for the sediments in the study area $[31,48]$.

3.4. PCA for HMs in Sediments. PCA can describe the common features in contents and spatial distribution of selected HMs and based on these features to recognize their origins. The first three components contributed $92 \%$ to the variance and all their initial eigenvalues are higher than 0.5 . The initial eigenvalues of the other four components are lower than 0.5 (Table S4), indicating that these components need not be discussed because they can explain little for the variability of HMs. As shown in Figure 4 and Table S5, principal components 1 (PC1) was predominantly controlled by $\mathrm{Pb}(0.87), \mathrm{Zn}(0.63), \mathrm{Cu}(0.96)$, and $\mathrm{As}(0.78)$ and these HMs accounted for $58.46 \%$ of the total variance. The study area is abundant in lead-zinc mineral resources and extensive mining such as activated slag stacking optionally for the long term, resulting in the sediments contaminated with $\mathrm{Pb}$ and $\mathrm{Zn}$. The association phenomena of $\mathrm{As}, \mathrm{Zn}, \mathrm{Pb}$, and $\mathrm{Cu}$ deposits were observed in the study area, where belongs to the low-temperature mineralization area. As they originated from the low-temperature, hydrothermal fluids can facilitate the epithermal deposits of these metals [49]. Therefore, positive relationships were found among these HMs, and they would exhibit common characters such as originating from the same source, enrichment, and transport. We thus concluded that PC1 was mainly from mining and smelting activities of lead-zinc mine.

Principle components 2 (PC2) was dominated by $\mathrm{Hg}$ (0.89) and $\mathrm{Zn}(0.69)$ and explained $18.61 \%$ of the total variance (Table S5). Guizhou province is located in the center of the circum-Pacific, where the content of $\mathrm{Hg}$ of natural soils is generally high because of high background values of $\mathrm{Hg}$ [48]. More importantly, Guizhou is a significant site for producing $\mathrm{Hg}$ in the world. Although all the large- 


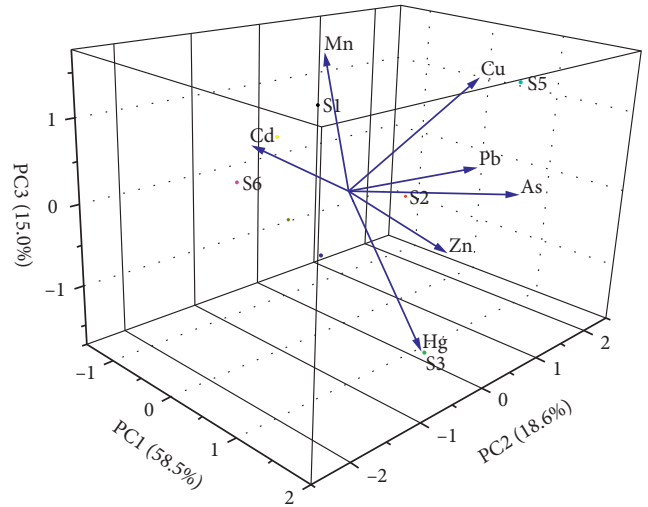

FIgURE 4: The three-dimensional output result of PCA.

scale mining activities for producing $\mathrm{Hg}$ had been ceased in the study area, the environment had been seriously contaminated with $\mathrm{Hg}$ already [48]. In addition, Guizhou province is rich in zinc ores, which contain a high level of Hg. The smelting activities of $\mathrm{Zn}$ can discharge a large amount of $\mathrm{Hg}$ into the environment $[48,50]$. Therefore, it was found that PC2 mainly came from soil surface runoffs, $\mathrm{Hg}$ mining activities, and smelting of $\mathrm{Zn}$.

Principle components 3 (PC3) can explain 14.99\% of the total variance and was dominated by Cd (0.95). Generally, $\mathrm{Cd}$ is the indicator element for agricultural activities, especially for livestock and poultry breeding [51]. Besides, activities of mining and smelting in the lead-zinc mine can discharge a large amount of $\mathrm{Cd}$ into the environment [52]. The spatial distribution characteristics of $\mathrm{Cd}$ showed that higher values of $\mathrm{Cd}$ concentrations were observed mainly in the region near the livestock rearing area and close to leadzinc mine, which supported these viewpoints. Therefore, the origins of $\mathrm{Cd}$ is mostly related to livestock and poultry breeding and lead-zinc mine.

3.5. Source Apportionment by PMF. Except for correlation analyses and PCA, the PMF model was run to identify where the HMs come from to the sediment more accurately. The minimum $Q$ true value was found for regulating the residual matrix $E$ and determining the reasonable factor numbers to obtain a rational result of PCA. $\mathrm{S} / \mathrm{N}$ ratios categorized all the HMs to be "strong." The factor number was set to 3,4 , and 5 , and the PMF model run 20 times. The $Q$ true value was smallest (3.62) if the factor number was set to be 3 . The fitting coefficients between the determined contents and the model predicted concentration were shown in Table S6. Although the fitting coefficient of $\mathrm{Hg}$ was relatively low, and of the other HMs was above 0.70 , which suggested that the fitting effects of PMF could elucidate the potential information of original data and then met the research needs.

Factor 1 was characterized by $\mathrm{Mn}$ and As (Figure 5(a)), and their corresponding contributions were calculated to be $64.2 \%$ and $45.7 \%$ (Table 2). Compared with the background level of $\mathrm{Mn}$, the concentrations of $\mathrm{Mn}$ in the sediments around this lead-zinc mine were higher, and their coefficient of variations was 59\% (Table 1). This demonstrated that anthropogenic activities had significant effects on the accumulation of $\mathrm{Mn}$ in the sediments around this lead-zinc mine. Mn contamination was correlated with the coal mining activities, which is consistent with the fact that Guizhou province is rich in coal sources [53]. All the contents of As in the study area were lower than its own background value, and the coefficient of variation of As was lower than that of the other HMs (Table 1), indicating that As originated from the parental materials of soil. Factor 1 was thus identified as an industrial source associated with coal mining.

Factor 2 was predominantly characterized by $\mathrm{Pb}, \mathrm{Hg}, \mathrm{Zn}$, and As (Figure 5(b)), and their contributions were calculated to be $75.2 \%, 73.8 \%, 73.3 \%$, and $51.4 \%$, respectively (Table 2). We could ignore the contribution of As because As originated from the parental materials of soil. The average contents of $\mathrm{Pb}, \mathrm{Hg}$, and $\mathrm{Zn}$ were greater than their own corresponding geological baseline, and the coefficient of variation of these HMs was higher than $70 \%$ (Table 1), indicating external sources were responsible for these HMs. In the study area rich in mineral resources with $\mathrm{Pb}, \mathrm{Zn}$, and $\mathrm{Hg}$ [48], extensive mining activities could result in the accumulation of these HMs in the sediments around this leadzinc mine. Therefore, factor 2 was related to mining and smelting activities.

Factor 3 was mainly characterized by Cd (Figure 5(c)), its contribution was $62.7 \%$ (Table 2). The contents of $\mathrm{Cd}$ in the sediments around the lead-zinc mine were greater than its own background value, and their coefficient of variations was calculated to be $28 \%$ (Table 1). This suggested that the contamination of $\mathrm{Cd}$ in the sediments around this lead-zinc mine was caused by human activities. It has been identified that mining and smelting activities of lead-zinc mine could strongly raise the contents of $\mathrm{Cd}$ in the environment [54-57]. In addition, Cd could be recognized as indicator elements for livestock and poultry breeding [51]. So it is was found that factor 3 was mainly induced from industrial and agricultural sources.

The results obtained from the PMF model showed that factor 1 (coal mining activities), factor 2 (lead-zinc mining and smelting activities), and factor 3 (lead-zinc mine and agricultural activities), respectively, contributed $24.1 \%$, $48.8 \%$, and $27.1 \%$ to the total sources of HMs in the 


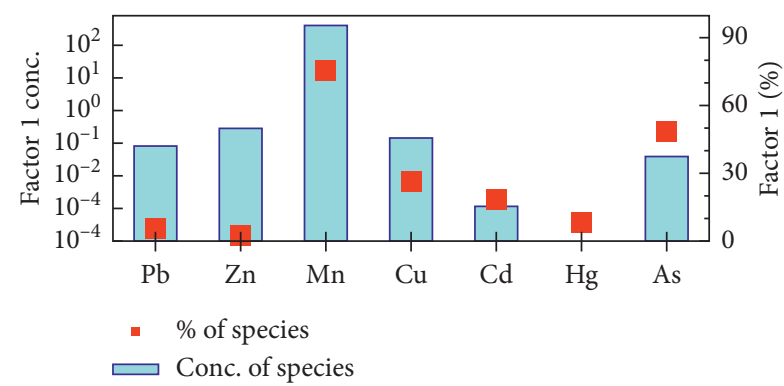

(a)

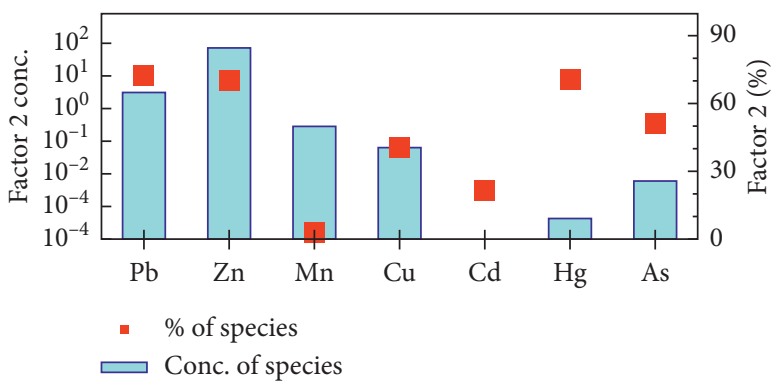

(b)

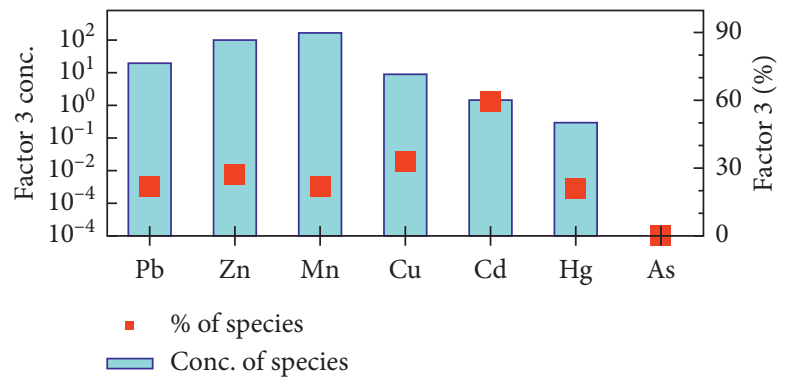

(c)

FIgUre 5: Apportioned results obtained from PMF model.

TABle 2: Contribution rates of factors to HMs in the sediments around this lead-zinc mine.

\begin{tabular}{lcccccc}
\hline & \multicolumn{3}{c}{ Source } & \multicolumn{3}{c}{ Source } \\
Element & \multicolumn{2}{c}{ profiles $/ \mathrm{mg}^{-1} \mathrm{~kg}^{-1}$} & \multicolumn{3}{c}{ contribution (\%) } \\
& F1 & F2 & F3 & F1 & F2 & F3 \\
\hline $\mathrm{Pb}$ & 7.21 & 70.2 & 16.0 & 7.73 & 75.2 & 17.1 \\
$\mathrm{Zn}$ & 17.7 & 294 & 89.4 & 4.41 & 73.3 & 22.3 \\
$\mathrm{Mn}$ & 499 & 11.1 & 267 & 64.2 & 1.43 & 34.3 \\
$\mathrm{Cu}$ & 6.28 & 11.5 & 9.40 & 23.1 & 42.2 & 34.6 \\
$\mathrm{Cd}$ & 0.319 & 0.614 & 1.57 & 12.7 & 24.5 & 62.7 \\
$\mathrm{Hg}$ & 0.150 & 1.09 & 0.237 & 10.2 & 73.8 & 16.1 \\
$\mathrm{As}$ & 3.27 & 3.68 & 0.205 & 45.7 & 51.4 & 2.87 \\
Total source & - & - & - & 24.1 & 48.8 & 27.1 \\
concentrations & & & & & & \\
\hline
\end{tabular}

“-”: not available.

sediments around this lead-zinc mine (Table 2). Compared with agricultural sources, the contamination of HMs in the sediments of the survey region was predominantly caused by lead-zinc mining and smelting activities.

\section{Conclusions}

Except for $\mathrm{Cu}$ and $\mathrm{As}$, the concentrations of selected HMs were greater than their own corresponding background levels. The concentrations of HMs together with their coefficient variations indicated that the river sediments around a typical lead-zinc mine were obviously contaminated with HMs and anthropogenic activities had significant effects on the accumulating of HMs. The concentrations of all HMs in the sediments showed significant variations among the sampling sites, and the higher contents of almost all HMs were mainly found in the sites near the lead-zinc mine.
The sediments around this lead-zinc mine were polluted to different degrees with various HMs based on different evaluation methods. Based on $P_{i}$, the sediments around this lead-zinc mine were heavily polluted with $\mathrm{Hg}, \mathrm{Zn}$, and $\mathrm{Cd}$, moderately polluted with $\mathrm{Pb}$, slightly polluted with $\mathrm{Mn}$, and nonpolluted with $\mathrm{As}$ and $\mathrm{Cu}$. The $I_{\text {geo }}$ indicated that the sediments were determined as heavily polluted with $\mathrm{Hg}$, moderately polluted with $\mathrm{Zn}$ and $\mathrm{Cd}$, slightly polluted with $\mathrm{Pb}$, and nonpolluted with $\mathrm{Mn}, \mathrm{Cu}$, and As. The PERI found that the ecological risks of HMs were predominantly caused by $\mathrm{Hg}$ and $\mathrm{Cd}$. In sum, $\mathrm{Hg}$, $\mathrm{Cd}, \mathrm{Zn}$, and $\mathrm{Pb}$ should be given careful consideration, and there was slight pollution or nonpollution with $\mathrm{Mn}, \mathrm{As}$, and $\mathrm{Cu}$ in the sediments around this lead-zinc mine.

Correlation analyses suggested that lead-zinc mining and smelting factory was the major source of $\mathrm{Pb}, \mathrm{As}, \mathrm{Zn}, \mathrm{Cu}$, and $\mathrm{Hg}$ in the sediments around this lead-zinc mine, and some other sources would also affect the contents of $\mathrm{Hg}$. PCA suggested that $\mathrm{Pb}, \mathrm{Cu}, \mathrm{As}$, and $\mathrm{Zn}$ predominantly came from mining and smelting activities of lead-zinc mine. $\mathrm{Hg}$ and $\mathrm{Zn}$ mainly came from soil surface runoff, $\mathrm{Hg}$ mining activities, and refining of $\mathrm{Zn}$. Cd was mostly associated with livestock and poultry breeding and lead-zinc mine. The PMF model found that Mn originated from coal mining activities, $\mathrm{Pb}, \mathrm{Zn}$, and $\mathrm{Hg}$ were from mining and smelting activities of lead-zinc, and Cd originated from lead-zinc mine and agricultural activities. In summary, the HMs contamination in the sediments around this lead-zinc mine was predominantly caused by lead-zinc mining and smelting activities.

\section{Data Availability}

The data on heavy metal contents of sampling sites, results of the evaluation, correlation analysis, PCA, and PMF are included within this article and the supplementary material. 


\section{Conflicts of Interest}

The authors declare that there are no conflicts of interest regarding the publication of this paper.

\section{Acknowledgments}

This work was financially supported by Science and Technology Department of Guizhou Province (No. Qian ke he ji chu [2020]1Z038) and the Doctoral Scientific Research Foundation of Guizhou Normal University for 2014 (No. 11904/0514154).

\section{Supplementary Materials}

Supplementary Materials: (a) Evaluation methods of contamination status of HMs. (b) Description of source apportionment by PMF. (c) Tables S1 and S2: the classification and indications of $I_{\text {geo }}$ and PERI. (d) Table S3: the results of correlation analysis. (e) Tables S4 and S5: the results of PCA. (f) Table S6: the results of PMF. (Supplementary Materials)

\section{References}

[1] S. Pandey, S. Parvez, I. Sayeed, R. Haque, B. Binhafeez, and S. Raisuddin, "Biomarkers of oxidative stress: a comparative study of river Yamuna fish Wallago attu (Bl. \& Schn.)," The Science of The Total Environment, vol. 309, pp. 105-115, 2003.

[2] R. Li, K. Shu, Y. Luo, and Y. Shi, "Assessment of heavy metal pollution in estuarine surface sediments of Tangxi River in Chaohu Lake Basin," Chinese Geographical Science, vol. 20, no. 1, pp. 9-17, 2010.

[3] D. Q. Chen, Z. Y. Xie, Y. J. Zhang et al., "Source apportionment of soil heavy metals in Guangzhou based on the PCA/APCS model and geostatistics," Ecology and Environmental Sciences, vol. 25, no. 6, pp. 1014-1022, 2016, (In Chinese).

[4] X. Bi, X. Feng, Y. Yang et al., "Heavy metals in an impacted wetland system: a typical case from southwestern China," Science of the Total Environment, vol. 387, no. 1-3, pp. 257268, 2007.

[5] R. Sun, J. Yang, P. Xia, S. Wu, T. Lin, and Y. Yi, "Contamination features and ecological risks of heavy metals in farmland along lake-shore zone of Caohai plateau wetland, China," Chemosphere, vol. 254, Article ID 126828, 2020.

[6] H.-n. Zhu, X.-z. Yuan, G.-m. Zeng et al., "Ecological risk assessment of heavy metals in sediments of Xiawan Port based on modified potential ecological risk index," Transactions of Nonferrous Metals Society of China, vol. 22, no. 6, pp. 14701477, 2012.

[7] R. Segura, V. Arancibia, M. C. Zúñiga, and P. Pastén, "Distribution of copper, zinc, lead and cadmium concentrations in stream sediments from the Mapocho River in Santiago, Chile," Journal of Geochemical Exploration, vol. 91, pp. 71-80, 2006.

[8] L. Hakanson, "An ecological risk index for aquatic pollution control.a sedimentological approach," Water Research, vol. 14 , no. 8 , pp. 975-1001, 1980.

[9] G. Müller, "Die Schwermmetallbelastung der sedimente des Neckars und seiner Nebenflusse: eine Bestandsaufnahme," Chemical Zeitung, vol. 105, no. 2, pp. 157-164, 1981.
[10] G. Onkal-Engin, I. Demir, and H. Hiz, "Assessment of urban air quality in Istanbul using fuzzy synthetic evaluation," Atmospheric Environment, vol. 38, no. 23, pp. 3809-3815, 2004.

[11] L. Fan, F. Chen, F. Chen, and Y. Fan, "Comprehensive assessment of soil environmental quality with improved grey clustering method: a case study of soil heavy metals pollution," Journal of Agricultural Science and Applications, vol. 01, no. 3, pp. 67-73, 2012.

[12] Y. Liu, L. Zhang, X. Han, T. Zhuang, Z. Shi, and X. Lu, "Spatial variability and evaluation of soil heavy metal contamination in the urban-transect of Shanghai," Environmental Science, vol. 33, no. 2, pp. 599-605, 2012, (In Chinese).

[13] Y. Chen, X. Jiang, Y. Wang, and D. Zhuang, "Spatial characteristics of heavy metal pollution and the potential ecological risk of a typical mining area: a case study in China," Process Safety and Environmental Protection, vol. 113, pp. 204-219, 2018.

[14] P. Xia, L. Ma, R. Sun et al., "Evaluation of potential ecological risk, possible sources and controlling factors of heavy metals in surface sediment of Caohai Wetland, China," Science of The Total Environment, vol. 740, Article ID 140231, 2020.

[15] Q. Liu, Z. Jia, S. Li, and J. Hu, "Assessment of heavy metal pollution, distribution and quantitative source apportionment in surface sediments along a partially mixed estuary (Modaomen, China)," Chemosphere, vol. 225, pp. 829-838, 2019.

[16] K. Zhao, L. Zhang, J. Dong et al., "Risk assessment, spatial patterns and source apportionment of soil heavy metals in a typical Chinese hickory plantation region of southeastern China," Geoderma, vol. 360, no. 15, Article ID 14011, 2020.

[17] T. Chen, X. Liu, M. Zhu et al., "Identification of trace element sources and associated risk assessment in vegetable soils of the urban-rural transitional area of Hangzhou, China," Environmental Pollution, vol. 151, no. 1, pp. 67-78, 2008.

[18] L. Cai, Z. Xu, M. Ren et al., "Source identification of eight hazardous heavy metals in agricultural soils of Huizhou, Guangdong Province, China," Ecotoxicology and Environmental Safety, vol. 78, no. 1, pp. 2-8, 2012.

[19] A. Lu, J. Wang, X. Qin, K. Wang, P. Han, and S. Zhang, "Multivariate and geostatistical analyses of the spatial distribution and origin of heavy metals in the agricultural soils in Shunyi, Beijing, China," Science of The Total Environment, vol. 425, pp. 66-74, 2012.

[20] R. Xiao, J. Bai, Q. Lu et al., "Fractionation, transfer, and ecological risks of heavy metals in riparian and ditch wetlands across a 100-year chronosequence of reclamation in an estuary of China," Science of The Total Environment, vol. 517, pp. 66-75, 2015.

[21] C. Ning, G. Li, Y. Wang, B. Li, L. Tian, and S. Wang, "Evaluation and source apportionment of heavy metal pollution in Xihe watershed farmland soil," Journal of AgroEnvironment Science, vol. 36, no. 3, pp. 487-495, 2017, (In Chinese).

[22] J. A. Luque-Espinar, E. Pardo-Igúzquiza, J. Grima-Olmedo, and C. Grima-Olmedo, "Multiscale analysis of the spatial variability of heavy metals and organic matter in soils and groundwater across Spain," Journal of Hydrology, vol. 561, pp. 348-371, 2018.

[23] A. Franco-Uría, C. López-Mateo, E. Roca, and M. L. Fernández-Marcos, "Source identification of heavy metals in pastureland by multivariate analysis in NW Spain," Journal of Hazardous Materials, vol. 165, no. 1-3, pp. 10081015, 2009.

[24] B. Dong, R. Zhang, Y. Gan et al., "Multiple methods for the identification of heavy metal sources in cropland soils from a 
resource-based region," Science of The Total Environment, vol. 651, pp. 3127-3138, 2019.

[25] A. Facchinelli, E. Sacchi, and L. Mallen, "Multivariate statistical and GIS-based approach to identify heavy metal sources in soils," Environmental Pollution, vol. 114, no. 3, pp. 313-324, 2001.

[26] Y.-G. Gu, Z.-H. Wang, S.-H. Lu, S.-J. Jiang, D.-H. Mu, and Y.-H. Shu, "Multivariate statistical and GIS-based approach to identify source of anthropogenic impacts on metallic elements in sediments from the mid Guangdong coasts, China," Environmental Pollution, vol. 163, pp. 248-255, 2012.

[27] Y. G. Gu, Q. S. Li, J. H. Fang, B. Y. He, H. B. Fu, and Z. J. Tong, "Identification of heavy metal sources in the reclaimed farmland soils of the Pearl River estuary in China using a multivariate geostatistical approach," Ecotoxicology and Environmental Safety, vol. 105, pp. 7-12, 2014.

[28] A. Das, S. S. Patel, R. Kumar et al., "Geochemical sources of metal contamination in a coal mining area in Chhattisgarh, India using lead isotopic ratios," Chemosphere, vol. 197, pp. 152-164, 2018.

[29] F. Huang, Y. Xu, Z. Tan et al., "Assessment of pollutions and identification of sources of heavy metals in sediments from west coast of Shenzhen, China," Environmental Science and Pollution Research, vol. 25, no. 4, pp. 3647-3656, 2018.

[30] S. S. Huang, Q. L. Liao, M. Hua et al., "Survey of heavy metal pollution and assessment of agricultural soil in Yangzhong district, Jiangsu Province, China," Chemosphere, vol. 67, no. 11, pp. 2148-2155, 2007.

[31] H. Ha, J. R. Olson, L. Bian, and P. A. Rogerson, "Analysis of heavy metal sources in soil using kriging interpolation on principal components," Environmental Science and Technology, vol. 48, no. 9, pp. 4999-5007, 2014.

[32] H. Song, K. Hu, Y. An, C. Chen, and G. Li, "Spatial distribution and source apportionment of the heavy metals in the agricultural soil in a regional scale," Journal of Soils and Sediments, vol. 18, no. 3, pp. 852-862, 2018.

[33] S. Tian, T. Liang, K. Li, and L. Wang, "Source and path identification of metals pollution in a mining area by PMF and rare earth element patterns in road dust," Science of The Total Environment, vol. 633, pp. 958-966, 2018.

[34] L. A. Rodenburg, S. Du, B. Xiao, and D. E. Fennell, "Source apportionment of polychlorinated biphenyls in the New York/New Jersey Harbor," Chemosphere, vol. 83, no. 6, pp. 792-798, 2011.

[35] J. Tan, J. Duan, Y. Ma et al., "Long-term trends of chemical characteristics and sources of fine particle in Foshan city, Pearl River Delta: 2008-2014," Science of The Total Environment, vol. 565, pp. 519-528, 2016.

[36] J. Liang, C. Feng, G. Zeng et al., "Spatial distribution and source identification of heavy metals in surface soils in a typical coal mine city, Lianyuan, China," Environmental Pollution, vol. 225, pp. 681-690, 2017.

[37] GPCCC (Guihzhou provincial chrography codification committee), Geology and Mineral Resources of Guizhou Provincial Chorography, Guizhou people's press, Guiyang, China, 1992.

[38] Q. Lin, Q. Li, L. Qu, H. Zhang, J. He, and H. Tan, “A preliminary study of mercury pollution in soil from the smeltery of Danzhai mercury mine," Guizhou Environment and Protection Sciences, vol. 4, no. 2, pp. 23-26, 1998, (In Chinese).

[39] D. Qiao, G. Wang, X. Li, S. Wang, and Y. Zhao, "Pollution, sources and environmental risk assessment of heavy metals in the surface AMD water, sediment and surface around unexploited Rona Cudeposit, Tibet, China," Chemosphere, vol. 248, Article ID 125988, 2020.

[40] CNEMC (China National Environmental Monitoring Center), The Soil Background Value in China, China Environmental Science Press, Beijing, China, 1990.

[41] Z. Xu, S. Ni, X. Tuo, and C. Zhang, "Calculation of heavy metals' toxicity coefficient in the evaluation of potential ecological risk index," Environmental Science \& Technology, vol. 31, no. 2, pp. 112-114, 2008, (In Chinese).

[42] G.-L. Yuan, T.-H. Sun, P. Han, J. Li, and X.-X. Lang, "Source identification and ecological risk assessment of heavy metals in topsoil using environmental geochemical mapping: typical urban renewal area in Beijing, China," Journal of Geochemical Exploration, vol. 136, pp. 40-47, 2014.

[43] P. Paatero, "Least squares formulation of robust non-negative factor analysis," Chemometrics and Intelligent Laboratory Systems, vol. 37, no. 1, pp. 23-35, 1997.

[44] L. P. Wilding, "Spatial variability: its documentation, accommodation, and implication to soil surveys," in Soil Spatial Variability, D. R. Nielsen and J. Bouma, Eds., pp. 166-194, Pudoc, Wageningen, Netherlands, 1985.

[45] J. Liu, Y. J. Liu, Y. Liu, Z. Liu, and A. N. Zhang, "Quantitative contributions of the major sources of heavy metals in soils to ecosystem and human health risks: a case study of Yulin, China," Ecotoxicology and Environmental Safety, vol. 164, pp. 261-269, 2018.

[46] J. Yoon, X. Cao, Q. Zhou, and L. Q. Ma, “Accumulation of Pb, $\mathrm{Cu}$, and $\mathrm{Zn}$ in native plants growing on a contaminated Florida site," Science of the Total Environment, vol. 368, no. 23, pp. 456-464, 2006.

[47] Y. Hu and H. Cheng, "Application of stochastic models in identification and apportionment of heavy metal pollution sources in the surface soils of a large-scale region," Environmental Science \& Technology, vol. 47, no. 8, pp. 3752-3760, 2013.

[48] X. Feng and G. Qiu, "Mercury pollution in Guizhou, Southwestern China-an overview," Science of the Total Environment, vol. 400, no. 1-3, pp. 227-237, 2008.

[49] G. Yang, "Statistical analysis of element combinations and their variations in the Shuicheng lead-zinc deposit," Geology and Exploration, vol. 50, pp. 303-310, 2014.

[50] P. Pai, D. Niemi, and B. Powers, "A North American inventory of anthropogenic mercury emissions," Fuel Processing Technology, vol. 65-66, pp. 101-115, 2000.

[51] C. Sun, J. Liu, Y. Wang, L. Sun, and H. Yu, "Multivariate and geostatistical analyses of the spatial distribution and sources of heavy metals in agricultural soil in Dehui, Northeast China," Chemosphere, vol. 92, no. 5, pp. 517-523, 2013.

[52] P. Xia, J. Zang, and X. Wang, "Geochemical characteristics and source analysis of heavy metals in surface sediment of Lianyungang area," Marine Environmental Research, vol. 30, no. 4, pp. 520-524, 2011, (In Chinese).

[53] M. A. Bhuiyan, L. Parvez, M. A. Islam, S. B. Dampare, and S. Suzuki, "Heavy metal pollution of coal mine-affected agricultural soils in the northern part of Bangladesh," Journal of Hazardous Materials, vol. 173, no. 1-3, pp. 384-392, 2010.

[54] Q. Guan, F. Wang, C. Xu et al., "Source apportionment of heavy metals in agricultural soil based on PMF: a case study in Hexi Corridor, northwest China," Chemosphere, vol. 193, pp. 189-197, 2018.

[55] X. Zhang, W. Fu, Y. Yin et al., “Adsorption-reduction removal of $\mathrm{Cr}(\mathrm{VI})$ by tobacco petiole pyrolytic biochar: batch experiment, kinetic and mechanism studies," Bioresource Technology, vol. 268, pp. 149-157, 2018. 
[56] P. Liang, X. Feng, Q. You et al., "Mercury speciation, distribution, and bioaccumulation in a river catchment impacted by compact fluorescent lamp manufactures," Environmental Science and Pollution Research, vol. 23, no. 11, pp. 1090310910, 2016.

[57] P. Liang, S.-C. Wu, J. Zhang, Y. Cao, S. Yu, and M.-H. Wong, "The effects of mariculture on heavy metal distribution in sediments and cultured fish around the Pearl River Delta region, south China," Chemosphere, vol. 148, pp. 171-177, 2016. 